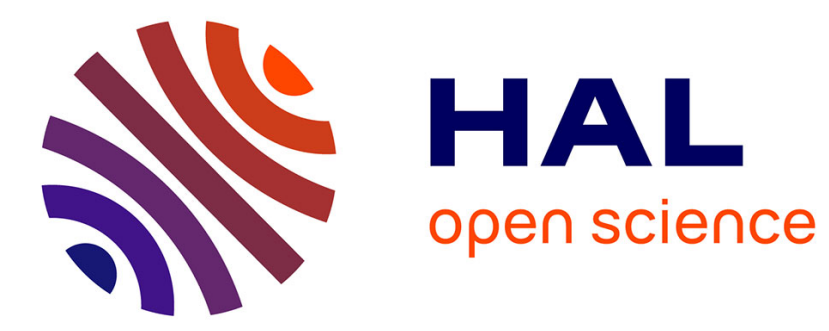

\title{
Does Forecasts Transparency Affect Macroeconomic Volatility in Developing Countries? Evidence From Quasi-Natural Experiments
}

Ummad Mazhar, Cheick Kader M'Baye

\section{To cite this version:}

Ummad Mazhar, Cheick Kader M'Baye. Does Forecasts Transparency Affect Macroeconomic Volatility in Developing Countries? Evidence From Quasi-Natural Experiments. 2014. halshs-00956454

\section{HAL Id: halshs-00956454 \\ https://shs.hal.science/halshs-00956454}

Preprint submitted on 6 Mar 2014

HAL is a multi-disciplinary open access archive for the deposit and dissemination of scientific research documents, whether they are published or not. The documents may come from teaching and research institutions in France or abroad, or from public or private research centers.
L'archive ouverte pluridisciplinaire HAL, est destinée au dépôt et à la diffusion de documents scientifiques de niveau recherche, publiés ou non, émanant des établissements d'enseignement et de recherche français ou étrangers, des laboratoires publics ou privés. 
Does Forecasts Transparency Affect Macroeconomic Volatility in Developing Countries? Evidence From Quasi-Natural Experiments

Ummad Mazhar, Cheick Kader M'baye 


\section{GATE Groupe d'Analyse et de Théorie Économique Lyon-St Étienne}

93, chemin des Mouilles 69130 Ecully - France

Tel. +33 (0)4 72866060

Fax $+33(0) 472866090$

6, rue Basse des Rives 42023 Saint-Etienne cedex 02 - France

Tel. +33(0)4 77421960

Fax. +33 (0)4 77421950

Messagerie électronique / Email : gate@gate.cnrs.fr

Téléchargement / Download : http://www.gate.cnrs.fr - Publications / Working Papers 


\title{
Does Forecasts Transparency Affect Macroeconomic Volatility in Developing Countries? Evidence From Quasi-Natural Experiments
}

\author{
Ummad Mazhar* \\ Cheick Kader M'baye ${ }^{\dagger}$
}

February 26, 2014

\begin{abstract}
In this paper, we empirically investigate the link between forecasts transparency and macroeconomic volatility as measured by inflation and output growth volatility in developing economies. We adopt the quasi-random controlled experiments methodology that divides our sample of 49 developing countries into three categories on the basis of their forecasts transparency. The first category is composed of central banks that are completely opaque over our sample period. The second type of countries is constantly transparent about their forecasts over the period of study while the third category includes central banks that have recently started to disclose their forecasts. In contrast to the previous literature, we interestingly find that increasing forecasts transparency unambiguously leads to higher macroeconomic volatility in developing countries. Indeed, we find that both groups of countries that constantly disclose their forecasts and that have only recently started to disclose their forecasts experience an increase in their macroeconomic volatility compared to the remaining group of countries that are completely opaque. Our results however indicate that forecasts transparency may have some stabilizing effects if and only if it is practiced along with other forms of institutional transparency.
\end{abstract}

Keywords: Forecasts transparency; monetary policy transparency; central banking; inflation volatility; output volatility.

JEL Classification: E58; E63; C33; C36.

\section{Introduction}

Monetary policy transparency has various dimensions. For reasons related to both economics and politics, a minimum level of transparency is considered desirable. An issue,

\footnotetext{
*Shaheed Zulfikar Ali Bhutto Institute of Science and Technology, 90-100 Clifton, Block 5, Karachi, Pakistan; Email: umadmazhar@gmail.com

${ }^{\dagger}$ Université de Lyon, Lyon, F-69007, France; CNRS, GATE Lyon Saint-Etienne, Ecully, F-69130, France; Université Lyon 2, Lyon, F-69007, France; Email: mbaye@gate.cnrs.fr.
} 
however, that still needs a consensus concerns the relationship between different forms of transparency and the macroeconomic environment. Both theoretical and empirical studies have contributed to this debate. From a theoretical perspective, an effective management of agents expectations for instance requires a future-oriented monetary policy. Even more important, forward-looking monetary policy reduces lags in the effects of policy decisions and helps to mitigate the rules versus discretions conflict in policy making (Svensson, 1997; Woodford, 2003 and 2007). Nonetheless, a number of recent studies find that greater disclosure of information can be harmful for stabilization policies ( Morris and Shin, 2002; Baeriswyl and Cornand, 2010; James and Lawler, 2011); or that ambiguity is welfare enhancing if it allows greater discretion in pursuing alternative policy goals (Cukierman and Meltzer, 1986; Geraats, 2007; Walsh, 2008).

Empirical findings on the effects of transparency also highlight the conflicting conclusions of the theoretical literature. For instance, among the few empirical studies on the issue, Demertzis and Hughes-Hallet (2007) find, contrary to their theoretical predictions, a positive relation between output volatility and transparency. Whereas, Chortareas et al. (2002) and Dincer and Eichengreen (2010) find that transparency reduces macroeconomic volatility.

It has been noted that empirical studies on the effects of transparency fail in many important aspects. For instance, a large part of the empirical literature focuses on a general measure of transparency assuming complementarity between various aspects of transparency. This assumption is not necessarily true as political transparency cannot complement forecasts transparency. Similarly, there are only few studies that relate the effects of transparency to its degree. In this regard, Van der Cruijsen et al., (2010) provide a robust evidence that an intermediate degree of overall transparency is optimal in reducing inflation persistence. What is still not known, however, is to what extent forecasts transparency is desirable in the presence of other forms of transparency.

This paper empirically contributes to this literature by focusing on the effects of forecasts transparency on macroeconomic volatility in developing countries. To our knowledge, this paper is the first one to apply the quasi-natural experiments methodology to deal with this issue. There is an abundant theoretical literature that favors forecasts transparency as a feature of monetary policy strategy (see van der Cruijsen and Eijffinger, 2010 for a survey). However, previous studies analyze the influence of transparency clubbing together its various aspects. Thus, there is no distinction between political transparency (which has average score of 2 across our sample of countries) and economic transparency (which has an average score of 0.60 across our sample of countries). It is only recently that empirical literature has started analyzing the individual impact of different forms of transparency and their relative desirability (Crowe and Meade, 2008; Cruijsen et al., 2010; Mazhar, 2013).

Our paper approaches the issue of forecasts transparency in two novel aspects. First, it designs a quasi-random experiment by dividing central banks into different groups according to their levels of forecasts transparency. Second, we focus on a relatively similar 
set of countries. Our sample includes 49 middle income economies where a middle income economy is defined to be either lower middle income or higher middle income economy following World Bank classification ${ }^{1}$. Despite being reasonably similar in their institutional setting and level of economic development, these countries exhibit significant differences in terms of forecasts disclosures. This allows us to perform a meaningful comparison across central banks with different transparency practices.

Our analysis draws on unique insights about transparency to particularly investigate the impact of forecasts transparency on inflation volatility and output growth volatility controlling for the influence of various other forms of transparency. Our findings interesting suggest that forecasts transparency has an independent and significant positive impact on macroeconomic volatility. In other words, forecasts transparency makes the macroeconomic environment more instable in developing countries. However, it may have some stabilizing effects only if it is practiced along with other forms of transparency components.

Our findings contribute to the existing literature in different ways. Firstly, as noted by Calvo and Mishkin (2003) and Fraga et al. (2003), developing countries are generally characterised by greater macroeconomic volatility compared to developed economies. Our findings suggests that monetary policy transparency can be one way of achieving greater stability if reliable forecasting communication mechanism is established along with other dimensions of transparency. Secondly, we try to quantify the effects of forecasts transparency and to highlight their relative worth in comparison to other sources of stabilization.

The rest of the paper is organized in the following way. Section 2 presents and describes our empirical methodology and dataset. Section 3 presents and analyzes our results. Finally, we present the conclusion of the paper in Section 4.

\section{Methodology and dataset}

Our methodology consists in differentiating between three types of countries in our sample of 49 middle income countries. In the first category, we have central banks with zero forecasts transparency. In other words, the first category includes those central banks that are completely opaque about their forecasts over our sample period that is, from 1998 to $2007^{2}$. The second group of countries is transparent about their forecasts but their forecasts transparency remains constant over the period of our study. The final category includes central banks that move from zero to positive transparency over our sample period.

Our measure of transparency comes from Eijffinger and Geraats (2006) transparency

\footnotetext{
${ }^{1}$ According to the World Bank classification, a middle income country is one having per capita GDP between 3976 to 12275 US dollars whereas lower middle income group have per capita income between 1006 to 3975 US dollars.

${ }^{2}$ Siklos (2011) provides transparency scores for 100 central banks over a period from 1998 to 2009. To avoid any issue relating to financial crisis which will complicate our analysis, we restrict the upper limit of our sample period to 2007.
} 
index (hence, EG index) which has become a standard gauge of transparency ${ }^{3}$. We use the EG index as updated by Siklos $(2011)^{4}$ to proxy transparency across different dimensions. The 5 components of the EG index are detailed in Table 1 in the Appendix. Each of these five components has three sub-indices. Hence, 15 sub-indices compose the general EG index. The minimum score of each sub-index is 0 , and the maximum is 1 , with higher score corresponding to higher level of transparency. Summing all the 15 sub-indices' scores yields the general EG index. Consequently, the EG index has a minimum of 0, and a maximum of 15 .

The classification of central banks in our sample depends on their forecasts transparency (sub-index B.1 in Table 1 in Appendix). The group of countries with zero forecasts transparency throughout the period of study (called ZeroTr group) is our control group. The group with positive forecasts transparency throughout the period is our treatment group (abbreviated as PositiveK). The third group (called ChangeTr) is primarily meant to highlight the before and after effect of switching from zero to positive forecasts transparency. Ideally we should compare the performance of the group PositiveK before 1998 to its performance over our sample period. However, it is not feasible as there is no forecasts transparency measure available for all the countries prior to 1998 period. Admittedly, absence of measure before 1998 does not mean absence of transparency. Thus, if we compare periods prior to 1998 with period of our study, we cannot identify causal effect of transparency. By number of countries, the largest category is Change $\operatorname{Tr}$ that includes 23 countries. The categories ZeroTr and PostiiveK contain respectively 19 and 7 countries. Table 2 in the appendix provides definitions and sources for all variables used in our study as well as our sample of countries, and summary statistics across our three groups are presented in Table 3.

\section{The empirical model}

Our empirical model estimates the following equation:

$$
\text { InfVolit }=f(\text { dummies of forecasts transparency, transparency, control variables }),
$$

where $i=1,2, \ldots, 49$ denotes country and $t=1998, \ldots, 2007$ denotes year.

A similar specification is used for output growth volatility $(\mathrm{Gr} V o l)$ as dependent variable. We calculate inflation volatility (respectively output growth volatility) as 5 years moving standard deviation. This technique is standard in the literature investigating the determinants of macroeconomic volatility (Blanchard and Simon, 2001; Cecchetti et al.,

\footnotetext{
${ }^{3}$ The EG index is however not free of weaknesses. As pointed out by Claussen (2008) many times transparency comparisons across central banks blow up the differences and lead to misleading conclusion. We believe that our sample being reasonably similar do not suffer from this weakness.

${ }^{4}$ Geraats (2002) classify five dimensions of transparency in terms of policy processes: political, economic, procedural, policy, and operational. Political transparency is about the clarity of objectives, economic transparency covers information used for the policy decision, procedural transparency relates to the decision making process, policy transparency to the monetary policy stance, and operational transparency to the effects of monetary policy implementation.
} 
2006).

As noted before, there are three categories of central banks in our sample according to their numerical forecasts disclosures. We include dummies for PositiveK and ChangeTr categories while taking Zero $T r$ as the reference category. The value of transparency scores (TrIndexAdj) is included after excluding the forecasts transparency component. In other words, this variable represents the scores of the EG index after the component numerical macroeconomic forecasts (aspect B.1 in Table 1) has been excluded.

In addition to forecasts dummies and transparency index, we also control for a number of relevant variables. For instance greater trade openness can increase or decrease the macroeconomic volatility depending upon various geographical, logistic, and terms of trade related factors (Bowdler and Malik, 2005). Previous studies also find a role for openness although its direction is not yet clear (Cecchetti et al., 2006; and Cabanilas and Ruscher, 2008). Moreover, it is important to control for openness and increased interdependence among countries to account for the impact of global conditions on individual economies (Stock and Watson, 2005). All these reasons give rational for the inclusion of openness in our empirical model.

To control for the effect of institutional factors and overall living standard, we include GDP per capita in purchasing power parity US dollars. However, we cannot expect a strong influence of GDP per capita on our dependent variables because of the relatively homogenous nature of our sample in terms of GDP per capita.

Many studies also point out the role of energy ratio (as a percentage of GDP) in reducing macroeconomic volatility. For example, Nakov and Pescatori (2010) show that a lesser reliance on oil mitigates the impact of oil price shocks. In particular, many middle income economies experience greater volatility because of their greater reliance on petroleum imports. Therefore, without controlling for the influence of this factor, it will be hard to interpret our estimates ceteris paribus.

Another important determinant of macroeconomic volatility is inventory investment. It is found that greater flexibility and timeliness in inventory management stabilizes output (McConell and Perez-Quiros, 2000). However, in cross-country setting, Cecchetti et al. (2006) and Cabanillas and Ruscher (2008) find that changes in inventory investment are negatively correlated with output volatility.

The share of services sector in the composition of GDP is found to have a stabilizing effect on output and price volatility. Arguably, increasing share of services in the GDP growth indicates an evolution of the economic structure towards higher stage of development. Therefore, we can expect the share of services to have a negative impact on output growth volatility.

Another issue we should consider is that, it is not obvious that transparency and macroeocnomic volatility are related linearly. Thus, to take into account this possible non-linear relationship, we also construct a non-linear model by introducing interaction terms. We believe that it will allow us to evaluate the robustness of the results we gather from the linear regression analysis. 


\section{Results}

As a first step towards our empirical analysis, we conduct a simple comparison of means test between our three groups of countries. To this end, we follow Wooldridge (2013) and run a simple regression with InfVol (respectively, GrVol) as our dependent variable taking each of the group dummy variable in return. This test tells whether the groups are significantly different from each other in terms of their macroeconomic volatility or not. For instance, our results in Table 4 indicate that central banks with Zero $\operatorname{Tr}$ have significantly low inflation volatility than all the rest. However, although their relatively less volatility is indicated by a negative coefficient on GrVol, it is not significant at conventional levels. Similarly, the category PositiveK exhibits a significantly more output growth volatility than all the rest of central banks, while central banks which change their forecasts transparency status experience a significantly greater inflation volatility than all the remaining groups of central banks in our sample. This test is very general as it cannot differentiate between the more than two categories at a time, which tends to limit its scope. Nevertheless, it allows us to acknowledge the existence of significant differences in the macroeconomic behavior between our three groups of countries.

Table 5 presents the results of the impact of forecasts transparency on inflation volatility. Our basic specification is presented in column (1). It contains transparency scores adjusted for forecasts transparency ( $\operatorname{Tr} \operatorname{IndexAdj}$ ) and two dummy variables which represent two out of three groups in our sample namely, PositiveK and ChangeTr. Among control variables, the basic specification includes Openness (Openness), GDP per capita (GDPpc) and energy ratio ( EnergyRatio).

As shown in the last row, the overall model is highly significant. The presented results are also robust against heteroskedasticity and autocorrelation for order one ${ }^{5}$. Our results indicate a significant negative effect of TrIndexAdj on inflation volatility. The coefficient has a meaningful magnitude indicating that a one percentage increase in the overall adjusted transparency index reduces the standard deviation of inflation by approximately 0.82 point. Putting this in our context, the mean value of inflation volatility in our sample is 4.51. Thus, our results indicate that for an average central bank, a one point increase in the adjusted transparency index, keeping all the other things unchanged, will reduce inflation volatility to 3.69 .

Openness is measured as a percentage of GDP. Its coefficient is negative but insignificant. Even when it is significant (as in models in columns (2) and (3)), it indicates a marginal reduction in inflation volatility. Thus, with reference to the regression in column (2), a one percentage increase in openness reduces inflation volatility by 0.02 per cent. This result may reflect an inadequate measurement of openness through the ratio of imports plus exports to GDP. Indeed, this measure ignores many factors that determine the impact of openness on macroeconomic variables such as the quality of institutions and logistic facilities.

\footnotetext{
${ }^{5}$ Specifically, we use Driscoll and Kraay (1998) standard errors that are robust against heteroskedasticity and autocorrelation.
} 
As for GDP per capita, it appears to have a significant positive impact on inflation volatility although this effect does not contain much economic magnitude. It may indicate inexistence of a linear relationship or an indirect relation between GDP per capita and inflation volatility.

We find that energy ratio has a significant negative impact on inflation volatility. This is consistent with the earlier findings documented by Nakov and Pescatori (2010) and Mazhar (2013). In terms of magnitude, a one percent increase in energy ratio reduces inflation volatility by 0.70 point. This result indicates that a more efficient use of energy or greater productivity due to technological improvement likely stabilizes inflation.

Our findings also indicate a stabilizing influence of inventory investment. Thus, greater efficiency and timeliness in the management of inventory reduces inflation volatility. According to our evidence, if inventory investment increases by a million US dollars, the inflation volatility will reduce by 1 point indicating a weak economic effect.

Coming to our variables of interest, we find that those central banks maintaining a positive level of macroeconomic forecasts transparency experience more inflation volatility than those which maintain zero forecasts transparency. More specifically, the estimated coefficient implies that the PositiveK group of countries has 3.4 points higher level of inflation volatility than the ZeroTr group. Similar pattern is displayed by the Change Tr group: It almost shows 4 points higher inflation volatility than the Zero Tr group. These results point out a novel aspect of transparency: increasing forecasts transparency increases inflation volatility at least in the case of developing countries. This is in contrast with previous studies which found a stabilizing effect of forecasts transparency (Chortareas et al., 2002).

Our findings could however be explained by the specific features of developing countries. As noted by Calvo and Mishkin (2003) and Fraga et al. (2003), one of the main characteristics of developing countries in general and emerging countries in particular is the presence of weak fiscal and monetary institutions. Weak fiscal institutions means that in order to finance their deficits, governments in these countries regularly put pressures on central banks so that to adopt inflationary policies leading to weak monetary institutions. As agents learn from the behavior of the central bank, increasing forecasts transparency will lead to greater volatility as they disbelieve in the ability of the central bank to provide reliable macroeconomic forecasts. Hence, being opaque about macroeconomic forecasts in these countries may be useful in the sense that it lessens reputation loss by hiding the real intents of central banks.

In columns (2) and (3) we add other important determinants of inflation volatility. In column (2) we add the share of services sector in GDP while in column (3) we add inventory investment change. The results in columns (2) and (3) remain similar to those in column (1). The positive effect of forecasts transparency on inflation volatility remains unchanged although the magnitude of the coefficients of dummy variables decreases in both cases.

It is possible that forecasts transparency has stabilizing properties when taken in re- 
lation to other aspects of transparency. To inspect this, we include interaction terms of our group dummy variable with $\operatorname{Tr} \operatorname{IndexAdj.~As~is~shown~in~column~(4),~our~con-~}$ trol variables (that is, GDP per capita and openness) now appear to be insignificant in mitigating inflation volatility. However, the results of transparency again indicate that forecasts transparency is harmful. The interaction effect of PostiveK and TrIndexAdj is positive and significant while the marginal effect of PositiveK is insignificant. On the other hand however, the interaction effect of Change $\operatorname{Tr}$ and TrIndexAdj is negative and significant, although the marginal effect remains significantly positive. This result indicates that even when its dependence on other forms of transparency is taken into account, forecasts transparency has ambiguous stabilizing effect on inflation volatility.

In Table 6 we follow the same specifications as in Table 5 but with output growth volatility as our dependent variable. In this case however, coefficients of control variables are less significant. For instance, openness has no significant effect on output growth volatility in any of the Table 6 regressions. Similarly, GDP per capita also has a negligible impact, if at all. Both share of services and inventory change reduce output growth volatility which is in line with the previous findings.

Again the dummy variables on forecasts transparency are mostly positive and significant. The results indicate that compared to central banks having zero forecasts transparency, those which remain consistently transparent over our sample period or those which turn toward forecasts transparency experience greater output growth volatility. This is particularly in contrast with the findings of Chortareas et al. (2002) who have shown that there is no evidence that forecasts transparency increases output volatility. However in terms of interaction terms (shown in column (4) in Table 6), the effect of both PositiveK and ChangeTr on output volatility is significantly negative indicating a stabilizing effect on output growth volatility. The marginal effect of PositiveK is nonetheless significantly positive but the marginal effect of Change $T r$ is insignificant.

To summarize our findings, we can put forward that forecasts transparency in itself unambiguously increases macroeconomic volatility in developing countries but if it is practiced along with other forms of institutional transparency, it is likely to have some stabilizing effects.

\section{Concluding remarks}

In this paper, we empirically analyze the effects of macroeconomic forecasts transparency on inflation and output growth volatility in developing countries. The previous literature, both theoretical and empirical, does not lead to a unanimous consensus about the relation between forecasts transparency and macroeconomic volatility. Given the relevance of forecasts transparency in forward-looking monetary policy effectiveness, it appears necessary to investigate more deeply this issue.

We however adopt a novel approach to this issue by performing a quasi-random controlled experiments methodology that divides our sample of 49 developing countries into 
three categories on the basis of their forecasts transparency practices. The first group, denoted by ZeroTr, is the one that never discloses any numerical forecasts over our sample period. The second category includes central banks that remain transparent over our sample period. Moreover, their transparency level remains unchanged over our estimation period. The third category includes countries that change their forecasts transparency score from zero to positive over our sample period that is, they are central banks that start disclosing forecasts only recently.

Our results indicate that compared to ZeroTr group, both PositiveK and ChangeTr groups experienced an increase in their macroeconomic volatility, while transparency scores (excluding forecasts transparency scores) appear to stabilize the macroeconomic volatility. These findings are robust to the inclusion of other determinants of macroeconomic volatility and interaction terms.

In terms of policy recommendation, our study has a clear message: forecasts transparency in itself unambiguously increases macroeconomic volatility in developing countries. However, it may have some stabilizing effects if and only if it is practiced along with other forms of transparency. But to the extent that these countries suffer from weak fiscal and monetary institutions, we recommend them to improve the quality of their institutions for instance by improving central bank independence along with increasing their level of overall transparency in order to insure strong macroeconomic effects of transparency policies.

Our evidence is based on a group of developing countries. An open avenue for future research is to perform the same analysis for developed economies so that to highlight more general policy implications. 


\section{References}

Baeriswyl, R. and Cornand, C. (2010). The signaling role of policy actions. Journal of Monetary Economics, 57(6):682 - 695 .

Blanchard, O. and Simon, J. (2001). The long and large decline in us output volatility. Brookings Papers on Economic Activity, 2001:135-164.

Bowdler, C. and Malik, A. (2005). Openness and inflation volatility: Cross-country evidence. Technical report, CSAE Working Paper Series 2005-08.

Cabanillas, L. and Ruscher, E. (2008). The great moderation in the euro area: What role had macroeconomic policies played? Technical report, European Commission Economic Papers No. 331

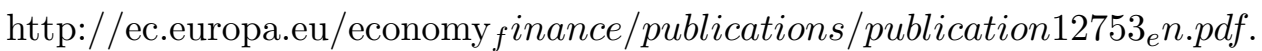

Calvo, G. and Mishkin, F. (2003). The mirage of exchange rate regimes for emerging market countries. Journal of Economic Perspectives, 17(4):99-118.

Cecchetti, S., Flores-Lagunes, A., and Krause, S. (2006). Assessing the sources of changes in the volatility of real growth. Technical report, NBER Working Paper No. 11946.

Chortareas, G., Stasavage, D., and Sterne, G. (2002). Does it pay to be transparent? international evidence from central bank forecasts. Federal Reserve Bank of St. Louis Review, pages $99-118$.

Claussen, C. (2008). Comparing monetary policy transparency: the eijffinger and geraats index - a comment. Technical report, Norges Bank Staff Memo 10.

Crowe, C. and Meade, E. (2008). Central bank independence and transparency: Evolution and effectiveness. European Journal of Political Economy, 24(4):763-777.

Cruijsen, C. V. D., Eijffinger, S., and Hoogduin, L. (2010). Optimal central bank transparency. Journal of International Money and Finance, 29(8):1482-1507.

Cukierman, A. and Meltzer, A. (1986). A theory of ambiguity, credibility and inflation under discretion and asymmetric information. Econometrica, 54:1099-1128.

Demertzis, M. and Hughes-Hallett, A. (2007). Central bank transparency in theory and practice. Journal of Macroeconomics, 29(4):760-789.

Dincer, N. and Eichengreen, B. (2010). Central bank transparency: Causes, consequences and updates. Theoretical Inquiries in Law, 11(1).

Driscoll, J. and Kraay, A. (1998). Consistent covariance matrix estimation with spatially dependent data. Review of Economic Statistics, 80:549-560.

Fraga, A., Goldfajn, I., and Minella, A. (2003). Inflation targeting in emerging market economies. Technical report, NBER Working Paper No. 10019. 
Geraats, P. M. (2002). Central bank transparency. Economic Journal, 112(483):532-565.

Geraats, P. M. (2007). The mystique of central bank speak. International Journal of Central Banking, 3:37-80.

James, J. and Lawler, P. (2011). Optimal policy intervention and the social value of public information. American Economic Review, 101(4):1561-74.

Mazhar, U. (2013). Transparency and output volatility: Empirical evidence. Technical report, Working Papers CEB 13-010, University Libre de Bruxelles.

McConnell, M. and Perez-Quiros, G. (2000). Output fluctuations in the united states: What has changed since the early 1980s. American Economic Review, 90:1464-1476.

Morris, S. and Shin, H. S. (2002). Social value of public information. American Economic Review, 92(5):1521-1534.

Nakov, A. and Pescatori, A. (2010). Oil and the great moderation. Economic Journal, 120:131-156.

Siklos, P. (2011). Central bank transparency: Another look. Applied Economic Letters, 18:929-933.

Stock, J. and Watson, M. (2005). Understanding changes in international business cycle dynamics. Journal of the European Economic Association, 3:968-1006.

Svensson, L. E. (1997). Inflation forecast targeting: Implementing and monitoring inflation targets. European Economic Review, 41:1111-1146.

Walsh, C. (2008). Announcement and the role of policy guidance. Federal Reserve Bank of St. Louis Review, 90:421-442.

Woodford, M. (2003). Imperfect Common Knowledge and the Effects of Monetary Policy, chapter In Phillipe Aghion, Robert Frydman, Joseph Stiglitz and Michael Woodford (Ed), Knowlelge, Information and Expectations in Modern Macroeconomics : In Honor of Edmund S. Phelps, pages 25-58. Princeton University Press, Princeton.

Woodford, M. (2007). The case for forecast targeting as a monetary policy strategy. Journal of Economic Perspectives, 21:3-24.

Wooldridge, J. (2013). Introductory Econometrics: A Modern Approach. South Western: USA., 5 edition. 


\section{Appendix}

\begin{tabular}{|c|c|}
\hline Major Index & Sub-index \\
\hline \multirow[t]{3}{*}{ A. Political Transparency } & 1. Monetary Policy Objectives \\
\hline & 2. With prioritization \\
\hline & 3. Explicit instrument independence \\
\hline \multirow[t]{3}{*}{ B. Economic Transparency } & 1. Numerical macroeconomic forecasts \\
\hline & 2. Quarterly, medium term for inflation and output \\
\hline & 3. Macroeconomic policy model \\
\hline \multirow{3}{*}{$\begin{array}{l}\text { C. Procedural } \\
\text { Transparency }\end{array}$} & 1. Monetary policy strategy \\
\hline & 2. Minutes \\
\hline & 3. Voting records \\
\hline \multirow[t]{3}{*}{ D. Policy Transparency } & 1. Policy adjustment \\
\hline & 2. Policy explanation \\
\hline & 3. Policy inclination \\
\hline \multirow{3}{*}{$\begin{array}{l}\text { E. Operational } \\
\text { Transparency }\end{array}$} & 1. Control error operating target \\
\hline & 2. Transmission disturbances \\
\hline & 3. Evaluating monetary policy outcomes \\
\hline
\end{tabular}




\begin{tabular}{|c|c|c|}
\hline Variable & Definition (Mean; St Dev) & Source \\
\hline InfVol & $\begin{array}{l}\text { Inflation volatility is the } 5 \\
\text { year moving standard } \\
\text { deviation of inflation where } \\
\text { inflation is annual percentage } \\
\text { change in consumer price } \\
\text { index }(4.51 ; 8.38) \text {. }\end{array}$ & $\begin{array}{l}\text { Inflation is taken from World } \\
\text { Economic Outlook, IMF (2011). }\end{array}$ \\
\hline GrVol & $\begin{array}{l}\text { Output growth volatility is } \\
\text { the } 5 \text { year moving standard } \\
\text { deviation of annual output } \\
\text { growth rate where annual } \\
\text { growth rate is the percentage } \\
\text { change in GDP in constant } \\
\text { 2005 Us dollars }(2.72 ; 1.79) .\end{array}$ & Same as above. \\
\hline TrIndexAdj & $\begin{array}{l}\text { An overall index of } \\
\text { transparency. Originally it } \\
\text { includes political, economic, } \\
\text { procedural, policy, and } \\
\text { operational aspects of } \\
\text { transparency. Included in the } \\
\text { regression after subtracting } \\
\text { the scores of forecasts } \\
\text { transparency (one of the sub- } \\
\text { components of economic } \\
\text { transparency) (4.06; 2.09). }\end{array}$ & $\begin{array}{l}\text { Eijffinger and Geraats (2006) } \\
\text { transparency index as provided } \\
\text { by Siklos }(2011) \text {. }\end{array}$ \\
\hline PositiveK & $\begin{array}{l}\text { A dummy variable for } \\
\text { forecasts transparency. It } \\
\text { assumes a value of } 1 \text { for } \\
\text { those central banks } \\
\text { maintaining full forecasts } \\
\text { transparency throughout our } \\
\text { sample period. The measure } \\
\text { of forecasts transparency is } \\
\text { one sub-index of Eijffinger } \\
\text { and Geraats transparency } \\
\text { index. Their measure of } \\
\text { forecasts transparency is } \\
\text { obtained as an answer to the } \\
\text { question: Does the central } \\
\text { bank regularly publish its } \\
\text { own macroeconomic forecast? }\end{array}$ & $\begin{array}{l}\text { Eijffinger and Geraats (2006) } \\
\text { transparency index as provided } \\
\text { by Siklos }(2011) \text {. }\end{array}$ \\
\hline
\end{tabular}




\begin{tabular}{|c|c|c|}
\hline Variable & Definition (Mean; St Dev) & Source \\
\hline ChangeTr & $\begin{array}{l}\text { A dummy variable for } \\
\text { forecasts transparency. It } \\
\text { assumes a value of } 1 \text { for } \\
\text { those central banks that have } \\
\text { changed their forecasts } \\
\text { transparency from zero to } \\
\text { positive over our sample } \\
\text { period. The measure of } \\
\text { forecasts transparency is one } \\
\text { sub-index of Eijffinger and } \\
\text { Geraats transparency index. } \\
\text { Their measure of forecasts } \\
\text { transparency is obtained as } \\
\text { an answer to the question: } \\
\text { Does the central bank } \\
\text { regularly publish its own } \\
\text { macroeconomic forecasts? }\end{array}$ & $\begin{array}{l}\text { Eijffinger and Geraats (2006) } \\
\text { transparency index as provided } \\
\text { by Siklos }(2011) .\end{array}$ \\
\hline Openness & $\begin{array}{l}\text { Percentage of imports plus } \\
\text { exports to GDP }(80.57 ; 35.89)\end{array}$ & $\mathrm{PWT}(2011)$ \\
\hline GDPpc & $\begin{array}{l}\text { GDP per capita in PPP US } \\
\text { dollars }(5759 ; 3372) .\end{array}$ & IMF (2O11) \\
\hline EnergyRatio & $\begin{array}{l}\text { GDP per unit of energy use is } \\
\text { the GDP per kilogram of oil } \\
\text { equivalent of energy use } \\
\text { where GDP is measured in } \\
2005 \text { constant purchasing } \\
\text { power parity dollars. }\end{array}$ & WDI (2011) \\
\hline ServShare & $\begin{array}{l}\text { Percentage value addition by } \\
\text { services sector in GDP of a } \\
\text { country }(53.73 ; 11.87) \text {. }\end{array}$ & WDI $(2011)$ \\
\hline InventChg & $\begin{array}{l}\text { It is the value of the change } \\
\text { in inventories (measured in } \\
\text { constant 2005 US dollars) } \\
(341.0 ; 1217) .\end{array}$ & $\begin{array}{l}\text { UN Data } \\
\text { http://data.un.org/Explorer.aspx }\end{array}$ \\
\hline
\end{tabular}




Table 2. (Continued)
Sample of countries (World Bank Classification, Total 49)
Positive but constant forecasts transparency (PositiveK): It includes all
the countries whose level of forecasts transparency remains positive but
unchanged throughout our sample period (that is, 1998-2007).
India, Mauritius, Moldova, Namibia, Solomon Islands, Sri-lanka, Uruguay
(Total 7).
Zero forecasts transparency (ZeroTr): It includes all the countries that
have zero forecasts transparency throughout our sample period.
Armenia, Bhutan, Bulgaria, Cuba, Egypt, El Salvador, Ghana, Guyana,
Jordan, Latvia, Libya, Lithuania, Mongolia, Nigeria, Pakistan, Russia,
Tunisia, Ukraine, Yemen (Total 19).
Change in forecasts transparency (ChangeTr): It includes all the
countries that have changed their transparency from zero to positive over
our sample period.
Albania, Argentina, Belarus, Belize, Brazil, Chile, China, Columbia, Fiji,
Georgia, Guatemala, Indonesia, Jamaica, Kazakhstan, Malaysia, Mexico,
Papua New Guinea, Peru, Philippines, Romania, South Africa, Thailand,
Turkey (Total 23).




\begin{tabular}{|l|c|c|c|c|c|c|}
\hline \multicolumn{7}{|c|}{ Table 3. Summary Statistics Across Groups } \\
\hline & \multicolumn{2}{|c|}{$\begin{array}{c}\text { ZeroTr } \\
\text { (19 countries) }\end{array}$} & \multicolumn{2}{c|}{$\begin{array}{c}\text { PositiveK } \\
\text { (7 countries) }\end{array}$} & \multicolumn{2}{c|}{$\begin{array}{c}\text { ChangeTr } \\
\text { (23 countries) }\end{array}$} \\
\hline & Mean(Std.Dev) & Obs. & Mean(Std.Dev) & Obs. & Mean(Std.Dev) & Obs. \\
\hline InfVol & $3.64(3.31)$ & 123 & $4.03(3.37)$ & 49 & $5.34(11.58)$ & 157 \\
\hline GrVol & $2.58(1.76)$ & 123 & $3.24(2.05)$ & 49 & $2.66(1.70)$ & 157 \\
\hline TrIndexAdj & $3.04(1.56)$ & 190 & $3.95(1.76)$ & 70 & $4.93(2.18)$ & 230 \\
\hline Openness & $81.10(30.57)$ & 190 & $85.14(32.48)$ & 70 & $78.74(40.64)$ & 230 \\
\hline GDPpc & $5339(3679)$ & 179 & $4644(3159)$ & 70 & $6425(3039)$ & 230 \\
\hline EnergyRatio & $4.65(2.31)$ & 167 & $7.60(4.06)$ & 58 & $6.12(2.75)$ & 208 \\
\hline ServShare & $51.27(14.11)$ & 178 & $57.96(6.29)$ & 70 & $54.36(10.81)$ & 227 \\
\hline InventChg & $101.4(414.7)$ & 166 & $256.2(728.4)$ & 70 & $539.8(1625)$ & 230 \\
\hline
\end{tabular}




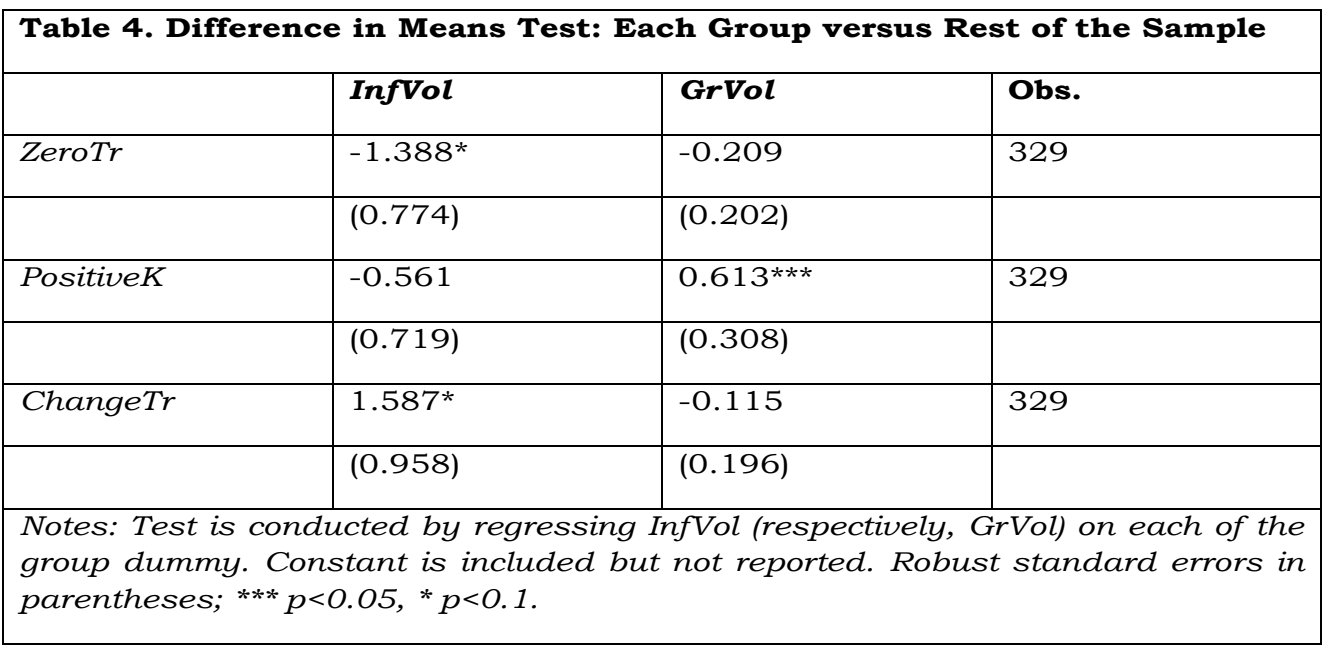


Table 5. Inflation volatility and forecasts transparency. Dependent Variable: Inflation Volatility

(1)

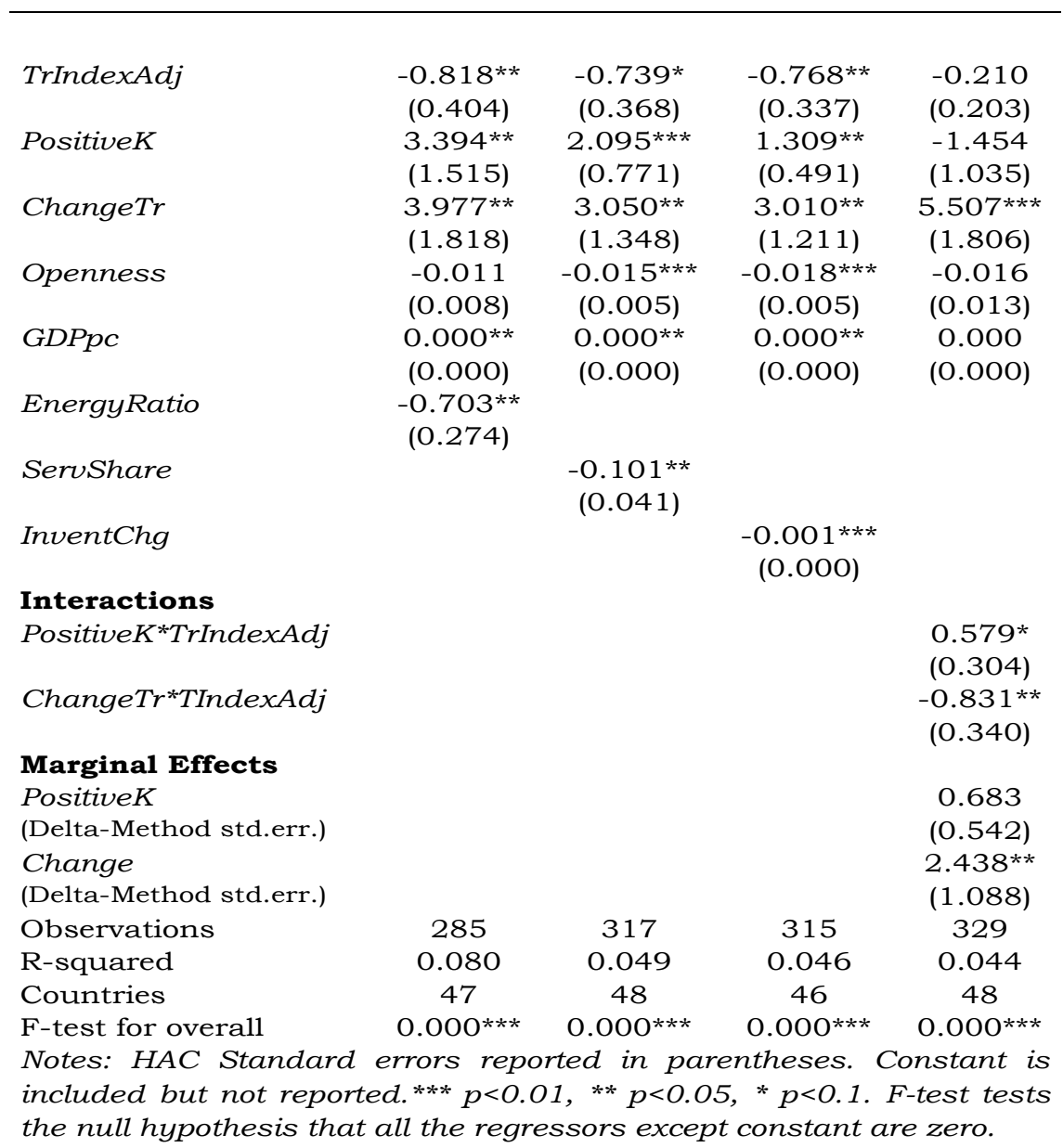


Table 6. Output growth volatility and forecasts transparency Dependent Variable: Output growth volatility

\begin{tabular}{|c|c|c|c|c|}
\hline & $(1)$ & $(2)$ & (3) & (4) \\
\hline TrIndexAdj & $\begin{array}{c}-0.166^{* * *} \\
(0.020)\end{array}$ & $\begin{array}{c}-0.200^{* * *} \\
(0.043)\end{array}$ & $\begin{array}{c}-0.211^{* * *} \\
(0.032)\end{array}$ & $\begin{array}{c}0.018 \\
(0.106)\end{array}$ \\
\hline PositiveK & $\begin{array}{c}0.499 \\
(0.334)\end{array}$ & $\begin{array}{c}1.314^{* * *} \\
(0.385)\end{array}$ & $\begin{array}{l}0.849 * * \\
(0.359)\end{array}$ & $\begin{array}{l}2.090 * * \\
(1.005)\end{array}$ \\
\hline ChangeTr & $\begin{array}{c}0.172 \\
(0.275)\end{array}$ & $\begin{array}{l}0.665^{* *} \\
(0.301)\end{array}$ & $\begin{array}{l}0.381^{*} \\
(0.225)\end{array}$ & $\begin{array}{c}1.182^{* * *} \\
(0.438)\end{array}$ \\
\hline Openness & $\begin{array}{l}-0.003 \\
(0.002)\end{array}$ & $\begin{array}{c}0.001 \\
(0.003)\end{array}$ & $\begin{array}{l}-0.001 \\
(0.002)\end{array}$ & $\begin{array}{l}-0.001 \\
(0.003)\end{array}$ \\
\hline$G D P p c$ & $\begin{array}{c}0.000 \\
(0.000)\end{array}$ & $\begin{array}{l}0.000 * \\
(0.000)\end{array}$ & $\begin{array}{c}0.000 \\
(0.000)\end{array}$ & $\begin{array}{c}0.000 \\
(0.000)\end{array}$ \\
\hline EnergyRatio & $\begin{array}{l}-0.037 \\
(0.041)\end{array}$ & & & \\
\hline ServShare & & $\begin{array}{c}-0.025^{* * *} \\
(0.008)\end{array}$ & & \\
\hline InventChg & & & $\begin{array}{c}-0.000 * * * \\
(0.000)\end{array}$ & \\
\hline \multicolumn{5}{|l|}{ Interactions } \\
\hline Positive $K^{*}$ TrIndexAdj & & & & $\begin{array}{l}-0.386 * \\
(0.230)\end{array}$ \\
\hline ChangeTr*TrIndexAdj & & & & $\begin{array}{c}-0.269 * * \\
(0.119)\end{array}$ \\
\hline \multicolumn{5}{|l|}{ Marginal Effects } \\
\hline \multicolumn{2}{|l|}{$\begin{array}{l}\text { PositiveK } \\
\text { (Delta-Method std.err.) } \\
\text { ChangeTr } \\
\text { (Delta-Method std.err.) }\end{array}$} & & & $\begin{array}{c}0.667^{*} \\
(0.354) \\
0.188 \\
(0.239)\end{array}$ \\
\hline Observations & 285 & 317 & 315 & 329 \\
\hline R-squared & 0.038 & 0.096 & 0.060 & 0.070 \\
\hline Countries & 47 & 48 & 46 & 48 \\
\hline $\begin{array}{l}\text { F-test for overall } \\
\text { Notes: HAC Standard } \\
\text { not reported. }{ }^{* * *} p<O . O 1 \\
\text { all the regressors excep }\end{array}$ & $\begin{array}{l}0.000^{* * *} \\
\text { reported } i \\
<0.05,{ }^{*} p< \\
\text { stant are } z\end{array}$ & $\begin{array}{l}\text { O.OOO } * * * \\
\text { arentheses } \\
\text { F-test tes }\end{array}$ & $\begin{array}{l}\text { O.OOO*** } \\
\text { Constant is } \\
\text { the null hy }\end{array}$ & $\begin{array}{l}0.000^{* * *} \\
\text { cluded but } \\
\text { thesis that }\end{array}$ \\
\hline
\end{tabular}

